University for Business and Technology in Kosovo

UBT Knowledge Center

UBT International Conference

2012 UBT International Conference

Nov 2nd, 9:00 AM - Nov 3rd, 5:00 PM

\title{
The challenges and the insurance industry analysis. The case of
}

\section{Albania}

\author{
Enida (Brakaj) Pulaj \\ University of Vlora, enidapulaj@yahoo.com \\ Amali Cipi \\ University of Vlora, amalia.cipi@gmail.com \\ Xhiliola (Shehu) Agaraj \\ University of Vlora, xhiliagaraj@yahoo.com
}

Follow this and additional works at: https://knowledgecenter.ubt-uni.net/conference

Part of the Business Commons

\section{Recommended Citation}

Pulaj, Enida (Brakaj); Cipi, Amali; and Agaraj, Xhiliola (Shehu), "The challenges and the insurance industry analysis. The case of Albania" (2012). UBT International Conference. 40.

https://knowledgecenter.ubt-uni.net/conference/2012/all-events/40

This Event is brought to you for free and open access by the Publication and Journals at UBT Knowledge Center. It has been accepted for inclusion in UBT International Conference by an authorized administrator of UBT Knowledge Center. For more information, please contact knowledge.center@ubt-uni.net. 


\title{
The challenges and the insurance industry analysis. The case of Albania
}

\author{
Enida Pulaj (Brakaj) ${ }^{1}$, Amali Cipi ${ }^{1}$, and Xhiliola Agaraj (Shehu) ${ }^{1}$, \\ ${ }^{1}$ Faculty of Economics, Management Department, University of Vlora “Ismail Qemali”, \\ enidapulaj@yahoo.com \\ amalia.cipi@gmail.com \\ xhiliagaraj@yahoo.com
}

\begin{abstract}
Like any other industry, the service industries need to be analyzed in the light of changes and reforms improving them. Based on the nature of the product, the analysis, that accompanies the development and reforms in these industries, is very important. In the world, we live in every moment we are endangered by a high uncertainty. Our life, our house, our wealth and everything we dispose, is threatened by loss, theft, damage or destruction. To avoid the high intensity of natural risk, there are created the insurance companies. The se companies cover the inability of insurers to take all the risk on themselves. The importance of security is higher in industrialized countries due to the high intensity of natural risk and the greatest concentration of population and great values in these countries. But, what happens with the insurance market in the country as Albania which has just passed a long period of transition
\end{abstract}

Keywords: industry, insurance industry, Albania, development, prime, damage.

\section{Introduction}

In the world, we live in every moment we are endangered by a high uncertainty. Our life, our house, our wealth and everything, we dispose, is threatened by loss, theft, damage or destruction. Who will turn us the burned house, the car damaged, the valu e of shares or bonds we dispose in a failed company? To avoid the high intensity of natural risk, are created the insurance companies. These companies cover the inability of insurers to take all the risk on themselves. The importance of security is higher in industrialized countries due to the high intensity of natural risk and the greatest concentration of population and great values in these countries.

Which is the importance of insurance?

Which are the dearest things for the people???!!!!!!!!!!

Once the Sydney police gave the evacuation order because of the fire that was approaching a peripheral neighborhood of this great city, its residents began to collect and save what they called the most important in their life. Among the first things, they have collected the family photo albums and security-notes. If the picture albums are so dear and costly for us, what can we say for the life of every individual?

The principal aim of this paper is to make an evaluation and to analyze the issues concerning the problems of in surance industry in Albania. An important place in this study has the determination of the factors which helps the development of this market.

The paper is structured in three parts:

- the evolution of the insurance market in Albania,

- the role of the insurance industry in Albanian economy,

- the way how the insurance market can be developed.

According the purpose of this work there are following the description and comparative methods.

\section{The evolution of the insurance market in Albania.}

Insurance in Albania have long existed, although they started very late compared with other developed countries (Zyka \& Stringa, 2010). So, the origin of the insurance companies is early. They have been on the rise phases and fall phases too. The insurance market in Albania has evaluated in several stages.

The first stage: Before the year 1944 the insurance activities in Albania were covered from the foreign insurance companies such as: Assicurazione General, Reunion Adriatica, Sicureta, and Assicurazione Industrial Socc ieta Tirana. Unfortunately, they were nationalized not in a good way in 1946. According to the book written by an Englishman in 1904, since 1900 the LLOYD'S had its subsidiaries in Shengjin, Durres and Vlore. 
The second stage has extended from 1948 to 1991. During this period, Albania was a country with centralized governance, the whole property belonged to the State, and the only insurance company was the State Insurance Institute that operated in the state's insurance market. In these circumstances such as the isolation from the outside world, the development of the security market in Albania passed through the path of stagnation because of the obligated used methods and the limited kinds and types of coverage.

If the nationalized process wouldn't be realized and the people would choose the voluntary insurance, the types of insurance coverage would be numerous and the cumulate experience would be extremely large. So, for the reasons, already, known there is used a scheme of compulsory coverage form.

The third stage: from 1991 and ongoing. After 1991, Albanian Insurance Institute (INSIG) was established. This company had a state owned capital and kept the monopoly of the insurance market in Albania until 1998. During this period were happened:

- The privatization of Albanian public company securities,

- The development of other insurance companies and

- The introduction of Albanian insurance market towards internationalization.

The globalization way would be attended from other existing and new insurance agents to maintain the continuously connection and improve the professional development of insurance industry in Albania.

\section{The role of the insurance industry in the Albanian economy.}

The Albanian insurance market started developing, mainly, after 1998(Gjergji, 2006). According to the IMF (2006), after undertaking many structural reforms, Albania was one of the country with the fastest growing rate regarding others transition economies. Despite its dismal initial conditions, Albania became one of the well performers in terms of macroeconomic performance, with a GDP per capita growth over the period 1992 to 2004 of more than 6 percent per year (Beck \& Laeven, 2006). Although this notable progress, Albania is still one of the poorest countries in Europe (Beck \& Laeven, 2006; Biberaj, 2011; p 387) according to major income indicators. The insurance market in the country remains undeveloped relative to its potential and compared with countries in the region. This fact is attributed to factors related to the developme nt of an economy still in transition and, in particular, low levels of incomes (Kume \& Xhuka, 2010). Another argument is still the weak culture of insurance because Albanian people insure in most cases only vehicles, responding to a legal obligation. They pay less money for life insurance, property, or health (AMF, Annual report 2010, 2011).

The insurance market has a very low level of security compared with other countries. In Albania, the insurance density rate (i.e. how much money per capita is annually spent on insurance products) is calculated approximately up to 20 euro per capita, or seven times lower compared with Bulgaria level up to 144 euro in 2008. The insurance market size may be measured by another indicator such as the insurance penetration rate.

The insurance market penetration (insurance premium volume in ratio to the GDP of each country) is different depending on countries, which shows that the insurance decision depends on the awareness and culture of individual for insurance (Sharku \& Bajrami, 2008). In Albania country, the awareness of citizens and businesses to be market insurance consumers is very low. Besides the lack of culture and the modest development of insurance market, the low level of Albania economy is another facto $\mathrm{r}$ that takes part in this industry. The low level of economy and living standard inherited from the socialism system in Albania, made the majority of the population to see the insurance market as a services provider not necessary for them or as they may be called "luxury services." Another factor obstructing the development of the insurance market is the fact that the level of damage repayment from insurance companies remains low.

The official data show that the report prime-damage value is estimated respectively $23 \%$ in 2009 , $30 \%$ in 2008 and average $45 \%$ in the region.

The statistics show that in our country, the structure of the insurance market is composed by two main types of activities. Thus, the insurance market is most oriented from compulsory insurance of motor vehicles and the other part from the voluntary insurance of life, houses etc. In these conditions, the growth of voluntary insurance is only as a result of banks requiremen ts to give loans or as a preliminary condition during the public procurement investment.

In a complex and dynamic world, the human and material damages are numerous which take a great monetary value. It is very important to understand that, after these situations where the damage reigns, there are insurance companies to improve the entities and individuals environment.

The necessity development of the insurance industry arises from several factors, but the basic fact remains that the insurance industry creates a guaranteed environment for our life. When we analyze the insurance market we should pay attention to the development of the private pension companies and other facilities belonging to the insurance market in general.

All over the world, referring the financial market, the insurance industry remains one of the basic pillars for the construction of society and its further development after the banking industry. Albania as a post-communist country has passed a long difficult period of transition. So, we can say, the Albanian economy has had all the characteristic of a country in transition, with both positive and negative tendencies. To illustrate this, we can remember the establishment of pyramidal firms which marked a negative impression in the economy and people's lives, or the undertaken reforms which help the improvement of the country. 
The role and the influence of the insurance industry are significant. It plays a key role in the Albanian economy and its res idents through claims and benefits paid to policyholders; investments; the payment of annual state tax revenue and job c reation. Thus, the number of employees 2011 in the insurance industry was average 1.115 with a growth trend of $4 \%$ compared to 2010 and 11\% compared to 2009 (AMF, 2011). Considerable attention has been devoted to evaluating the relationship between economic growth and insurance market deepening. This fact creates a financial stability, more liquidity and opportunities for further investments and growth. If the insurance index per capita would be higher than it really is, then the liquidity within this industry would be higher which means more money route and circulation between the agents of the market, the banks will have more deposits and the economy will have too much breathing.

Last years it has become an increasingly component of the financial sector, providing financial services to economy activity and to the individual. If we make a comparison of statistics to highlight the development of the insurance market, it is necessary to see the changes of statistics regarding voluntary and compulsory insurance. The indexes of the years show that both types of insurances are increased except the index of obligatory insurance in 2011. A significant growth is observed with the voluntary insurance indicators due to the reforms that have been taken in the insurance market regarding the awareness and promoting the security of individuals and companies.

Figure 1: Market development compulsory and voluntary insurance

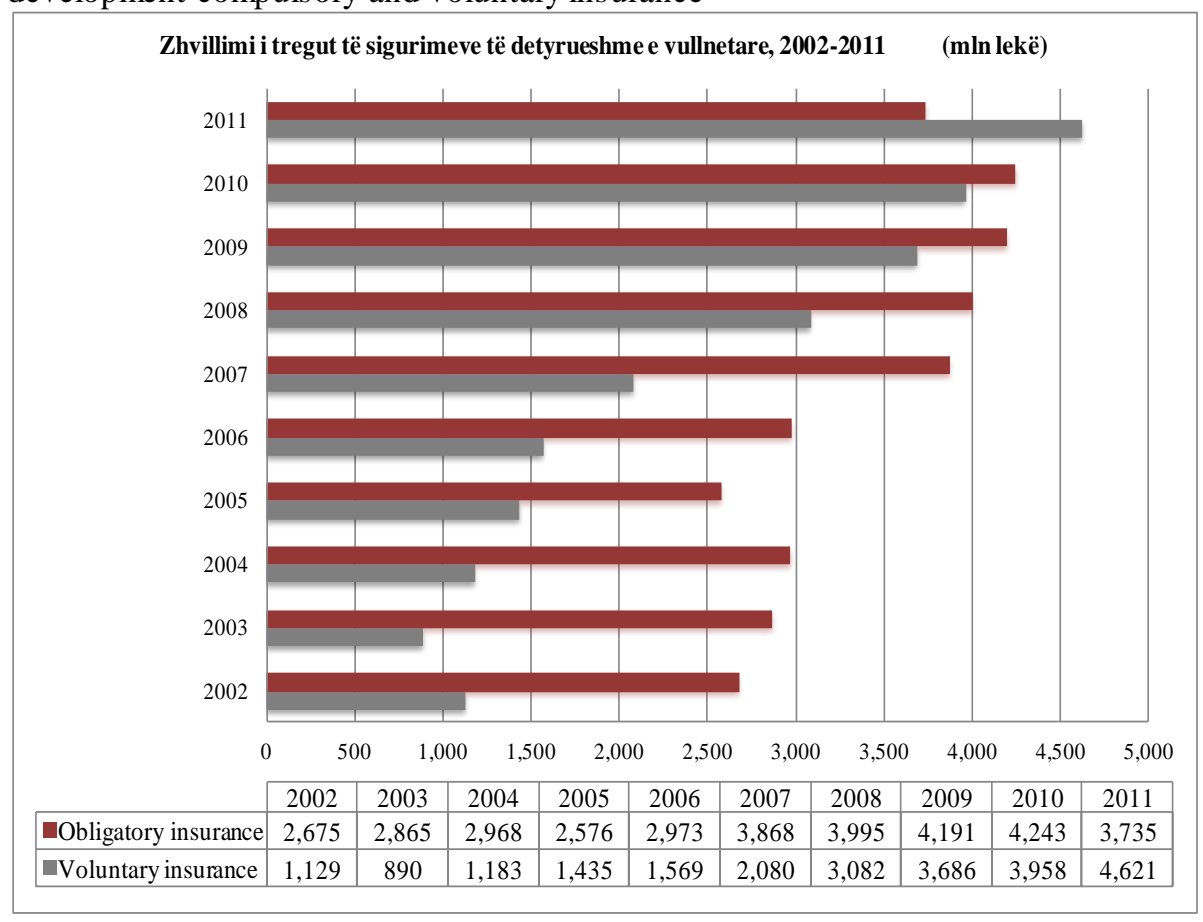

Source: AMF, Raporti vjetor 2011

Among other challenges, the problems related with this industry is the tendency of the insurance companies to increase just the number of insured individuals and companies but not the wide range and types of the services that characterize the insurance market in order to reduce the rivalry through differentiation products strategy. Thus, after 2004, five new insurance companies entered the market doubling the number of operators, up to 10 and increasing the competition. Albanian insurance companies implemented a very aggressive expanding policy by having branches even in Kosovo and Macedonia (ISA, 2004). In this conditions, it it is advisable for companies to use competitive strategies through low cost or/and differentiation (Porter, 1980) to increase market share and providing appropriate problem`s solution.

\subsection{How can the insurance market be developed in Albania?}

The insurance market in Albania already exists. The industry is experiencing significant and ongoing change and is being buffeted by challenging regulatory, political, and economic winds. There are 10 strategic participants in this market, such as Insig sha, Albsig, Sigma, Interalbania, Uniqa Austria group, Wienna group, etc., 2 of which are life insurance companies and INSIG, which, with a special law approved by parliament, offers both life and non-life services and products. Besides the reforms undertaken in this industry regarding the legal aspects, a high importance has the growth of people awareness, transparency and the high prime from insurance companies.

An important element of the development of this market is the creation of individual responsibilities to be protected from unpleasant situations and disasters, and the "removal" of the state responsibility from every damage occurred. This happened to leave the state government dealing with the improvement of financial market policy development and the completion of the legal 
framework, which often presents gaps and incomplete space that in some cases create the suitable environment for abuse. Therefore, the role of the state and other organizations that assist the development of this market is a consultative and regulatory between insurance companies and consumers.

From the experiences of companies which internationalized at the insurance market another key factor for success is the adaptation of their strategies with the country in which they are deployed. Another problem that requires solution is the awareness increase of the Albanian people for the importance of the life insurance. Insurance culture should be part of learn ing cycles so that people understand their real significance. People need to understand how valuable insurance contract and how they are helpful in case of damages (Agalliu, 2012).

Life insurance is offered to the clients on facultative basis (Sharku et al, 2011). According to Insurance Supervisory Authority (ISA), among main factors of compulsory insurance domination is the existence of a relatively low level of incomes of the population regarding the voluntary insurance. So, it is very difficult that Albanian consumer takes in consideration such policies as investment. The improvement of personal finance, the belief on insurance companies and the insurance culture are the key ways for industry development.

\section{Conclusion}

Development of the insurance market has encountered difficulties in economic and social character inherited from the communist system. Currently, the insurance market in Albania is focused on drafting the reforms, completing the legal framework for the avoidance of possible legal vacuum. It is evident that the insurance business in Albania remains underdeveloped and far from its potential. This is especially the case of life insurance sector, which has the lowest level a nd the influence of factors such as low level of personal income and the weak culture of insurance exhibited by the Albanian's people. Consequently, we conclude that insurer companies and the government have to work hard to encourage a better unders tanding of both insurance services and products and the risk that threat everyday life.

The internationalization of markets is the current tendency of the economy throughout the world. This strategy is part of policy development and the increase of the insurance market in Albania. Regarding the conditions and the development stage in the Albanian insurance market we recommend:

- The insurance market in Albania is a potential market and it is one of the markets in Albania that has different problems.

- The awareness increase of the Albanian people for the importance of the insurance market.

- The designing of short-run and the long-run strategies are very important for the development of the insurance market. The insurance strategies help the market to coordinate the movement of its players.

- The implementation of successful cooperation with foreign companies and the compliance of foreign strategies with our country.

To resolve the insurance market challenges, it is necessary to collaborate all the insurance companies with each other, the p roper state authority's collaboration, implementation of new politics and procedures in order to improve their performance, investments in staff knowledge, invest in new products and to implement the best method in collaboration with the customers.

\section{References}

Albanian Financial Supervisory Authority (AFSA/A MF), Annual Report 2010.

Albanian Financial Supervisory Authority (AFSA/AMF), AnnualReport 2011.

Agalliu, A. (2012). Insurance Companies Problems and challenges of this potential market in Albania. Science Journal of

Economics. Volume 2012, Article ID sje-Research Article 179, 4 Pages, 2012. doi: 10.7237/sje/179

Beck, Th. \& Laeven, L. (2006). Institution Building and Growth in Transition Economies. World Bank Policy Research Working Paper No. 3657. Retrieved on line at http://papers.ssrn.com/sol3/papers.cfm?abstract id=757865

Biberaj, E. (2011). Albania, The challenges of transition. Central and East European Politics: From Communism to Democracy. Edited by: Sharon L Wolchik \& Jane Leftwich Curry. Second edition. Rowman \& Littlefield Publishers.Inc.

Gjergji, A. (2006). Does Albania Have a Developed Financial Market?! Non-banking sector, not functioning pillar of the system. Paper submitted for "EU Membership \& Transformation"course, Warsaw School of Economics, Poland,

IMF - International Monetary Fund (2006), World economic outlook, April 2006: Globalization and inflation, World Economic and Financial Surveys.

Insurance Supervisory Authority (ISA), “Annual Report 2004”, Tirana

Kume, V. \& Xhuka, Z. (2010). Innovation Management in the Insurance Sector in Albania. Entrepreneurship and Innovation

Journal. Vol 3(3),pp. 95-107

Porter, M. (1980). Competitive Strategy: Techniques for Analyzing industries and competitors. New York

Sharku G., Bajrami E., (2008) "The impact of insurance culture in development of the insurance market in emerging economies

- case of Albania". Paper presented at International Conference on Management and Economics (ICME'08), Tirana, and March 2008 (pp. 77-99). 
Sharku, G., Leka, B., Bajrami, E. (2011). Considerations on Albanian Life Insurance Market. The Romanian Economic Journal. Year XIV, no. 39, pp. 133-150

Zyka E., Stringa A. (2010). “The development of Albanian Insurance Market”, Euroeconomica, Vol. 25, No 2, pp 54-62. 